\title{
The Economic Interest Test and Collective Action Problems in Antitrust Tie-in Cases
}

\author{
Theodore Frank $\uparrow$
}

A manufacturer of a patented salt-processing machine requires lessees to use only salt purchased from the manufacturer. ${ }^{1}$ A film distributor selling the rights to broadcast Casablanca requires television stations to also purchase the immensely less popular Tugboat Annie Sails Again. ${ }^{2}$ What do these seemingly disparate cases have in common? Both are examples of illegal "tie-ins," defined by the Supreme Court as restrictive agreements by a seller with market power (the "tier") that condition the sale of a more attractive product (the "tying product") on the buyer's promise to buy some other product (the "tied product"). ${ }^{3}$ However, this definition includes some tie-ins that the Court has ruled legal. For example, a publishing company can require that advertisers purchase space in both its morning and evening newspapers. ${ }^{4}$ And in a recent opinion, the Supreme Court implied that while a tie-in of copier parts with copier service might be illegal, a tie-in of copiers with copier parts and service would not be. ${ }^{5}$

Such opinions are difficult to reconcile and lead to confusion among businesses, lawyers, lower courts, and arguably the Supreme Court itself. To distinguish beneficial tie-ins from harmful ones, courts rely on a set of arbitrary legal definitions unsuited for the task. To make matters worse, the standard for per se illegality of tie-ins has shifted over time, becoming increasingly confused in the wake of Jefferson Parish Hospital Dist. No. $2 v$ Hyde. $^{6}$

Economists have identified several reasons why many tie-ins, though illegal under current antitrust doctrine, are actually beneficial to society. This Comment identifies another socially

$\dagger$ B.A. 1991, Brandeis University; J.D. Candidate 1994, The University of Chicago.

1 International Salt Co., Inc. $v$ United States, 332 US 392, 394 (1947).

2 United States $v$ Loew's Inc., 371 US 38, 41-42 (1962).

3 See Northern Pacific Railway Co. v United States, 356 US 1, 5-6 (1958).

4 Times-Picayune Publishing Co. v United States, 345 US 594, 624 (1953).

- Eastman Kodak Co. $v$ Image Technical Services, Inc., 112 S Ct 2072, 2078 (1992). Compare id at 2096 (Scalia dissenting) (noting that "this makes no sense").

${ }^{6} 466$ US 2 (1984). 
useful purpose served by tie-ins: in certain circumstances, they can help solve collective action problems. These problems have been recognized in other antitrust contexts, most notably in resale price maintenance cases. In the tie-in context, collective action problems are especially likely to lead to tying arrangements beneficial to consumers in cases where the seller has no "economic interest" in the tied product-for example, where a fast-food franchisor requires franchisees to purchase supplies from an unaffiliated seller.?

In the past, courts distinguished non-economic interest cases from other tie-ins by refusing to impose liability without a finding of a direct "economic interest" in the sale of the tied product. More recent decisions have undermined or even abolished the economic interest requirement, resulting. in potential liability and litigation expenses for harmless transactions. ${ }^{8}$ Analysis of the economic interest cases has further, unrealized implications for tie-in cases involving a seller who is not trying to dominate the tied product market, even though the seller has a direct economic interest in the sale of the tied product.

To better understand the approach that courts should take in dealing with tie-ins aimed at solving collective action problems, this Comment will first examine what tie-ins are and how companies employ them to resolve, among other issues, collective action problems. The Comment will then examine the history of the economic interest test, and will explain how courts have recently shorn it from its original doctrinal and economic moorings. By reviving the economic interest test in its original form-and thus reclassifying a class of beneficial tie-ins from per se illegal to per se legal-much needless litigation could be avoided. Restoring the original test and applying it to tie-in cases outside the collective action sphere should also help rationalize tie-in doctrine generally. ${ }^{9}$

7 See, for example, Kentucky Fried Chicken Corp. v Diversified Packaging Corp., 549 F2d 368, 377 (5th Cir 1977).

8 Compare Gonzalez v St. Margaret's House Housing Development Fund Corp., 880 F2d 1514 (2d Cir 1989) (rejecting an economic interest requirement), with Beard $v$ Parkview Hospital, 912 F2d 138, 144 (6th Cir 1990) (refusing to prohibit an arrangement without a direct economic benefit to the seller of tying product). See also Note, The Economic Interest Requirement in the Per Se Analysis of Tying Arrangements: A Worthless Inquiry, 58 Fordham L Rev 1353 (1990); Casenote, Antitrust-The Absence of an Economic Interest Requirement in Tying Arrangements, 63 Temple L Rev 595 (1990).

9 For a more complete inquiry into the need for per se legality rules in antitrust, see Frank H. Easterbrook, Allocating Antitrust Decisionmaking Tasks, 76 Georgetown L J 305 (1987). 


\section{ECONOMIC THEORY}

\section{A. Tie-ins and Other Antitrust Issues}

Because antitrust laws seek to regulate economic behavior, it is not surprising that economic analysis informs the study of antitrust doctrine. Courts have defined standards for antitrust in ways not always consistent with economic theory. ${ }^{10}$ Since the early years of the Burger era, the Supreme Court has proven increasingly willing to discard aspects of antitrust doctrine that are economically unsound. ${ }^{11}$ The courts continue to lag behind economists, however, in their treatment of tie-in cases.

Courts have often deemed tie-ins invalid on the basis of what might be called the "leverage argument." Proponents of this argument believe that a seller possessing market power with respect to one product can sometimes leverage that power on behalf of a second product in another market. By so leveraging its way into the second market, the seller unfairly restrains trade. To limit the monopolist's ability to reap these "leveraging gains," the argument concludes, a per se ban on tying arrangements is necessary. ${ }^{12}$ While only implicit in some of the early cases dealing

10 Frank H. Easterbrook, The Limits of Antitrust, 63 Tex L Rev 1 (1984) (tension exists because people litigate new business practices before economists fully analyze them). See also, more generally, Richard A. Posner, The Chicago School of Antitrust Analysis, 127 U Pa L Rev 925 (1979); Richard A. Posner, Antitrust Law: An Economic Perspective (Chicago, 1976); Robert H. Bork, The Antitrust Paradox (Basic Books, 1978).

i1 See E. Thomas Sullivan and Jeffrey L. Harrison, Understanding Antitrust and its Economic Implications § 4.02 at 73-74 (Matthew Bender, 1988). For examples of the Court's greater willingness to weigh economic factors instead of relying on traditional per se analysis, see Brooke Group Ltd. v Brown \& Williamson Tobacco Corp., $113 \mathrm{~S} \mathrm{Ct} \mathrm{2578,}$ 2588 (1993) (stating that "below-cost pricing . . . is of no moment to the antitrust laws if competition is not injured"); Matsushita Electric Industrial Co. v Zenith Radio Corp., 475 US 574, 594-595 (1986); NCAA $v$ Board of Regents of the University of Oklahoma, 468 US 85, 98-104 (1984); Broadcast Music, Inc. v Columbia Broadcasting System, Inc., 441 US 1, 13 (1979); United States v United States Gypsum Co., 438 US 422, 456 (1978).

12 See generally M.L. Burstein, A Theory of Full-Line Forcing, $55 \mathrm{Nw}$ U L Rev 62 (1960); James M. Ferguson, Tying Arrangements and Reciprocity: An Economic Analysis, 30 L \& Contemp Probs 552 (1965); Louis Kaplow, Extension of Monopoly Power Through Leverage, 85 Colum L Rev 515, 516-17 (1985). 
with tie-ins, ${ }^{13}$ the leverage argument has become explicit in more recent cases. ${ }^{14}$

Courts' hostility to tie-ins also stems from the claim that tieins increase barriers to entry in the tied product market. ${ }^{15}$ When the tier has no economic interest in the tied goods, the barrier to entry should not be of concern; manufacturers of the tied goods face no more barriers when competing to sell to the tier than they would in normal competition. ${ }^{16}$

Economists criticize tie-in law because of its foundations in theories of leverage and entry-barriers. For example, Judge Posner rejects the notion that it is possible to use leverage in such a way to gain additional monopoly profits. ${ }^{17} \mathrm{~A}$ monopolist cannot create additional power where none exists. For example, if a person is willing to pay $\$ 10$ for a minute of computer time and a hundred punch cards, it is irrelevant how the computer time or punch cards are priced, so long as the total price does not exceed $\$ 10$. The monopolist will not make any additional profit from having a second monopoly, for if she raises the price on the tied product (the punch cards), she will have to lower it on the tying product (the computer time). In fact, the variation in pricing may well reduce allocative losses from the level resulting had the

${ }^{13}$ Henry $v$ A. B. Dick Co., 224 US 1, 53 (1912) (White dissenting) (observing that by allowing a patentee to extend its patent rights over other, unpatented products, the Court was enabling patentees to "multiply monopolies at [ ] will"); Motion Picture Patents Co. $v$ Universal Film Manufacturing Co., 243 US 502, 517-18 (1917) (preventing the holder of a patent on movie projection equipment from requiring its licensees to use only film made by the patent holder); United Shoe Machinery Corp. $v$ United States, 258 US 451, 457-58 (1922) (finding that tying requirements by an equipment manufacturer extended its monopoly). See also Posner, Antitrust Law at 172 (cited in note 10); Kaplow, 85 Colum L Rev at 515.

14 Jefferson Parish, 466 US at 14 (if leverage "is used to impair competition on the merits in another market, a potentially inferior product may be insulated from competitive pressures”). But see Alaska Airlines, Inc. v United Airlines, Inc., 948 F2d 536, 545 (9th $\mathrm{Cir} 1991$ ) (rejecting leverage argument in context of a monopolization claim).

${ }_{15}$ Jefferson Parish, 466 US at 14; Lawrence A. Sullivan, Handbook of the Law of Antitrust 447-48 (West, 1977). But see Bork, Antitrust Paradox at 374-75 (cited in note 10) (noting that the most a monopolist can do is slow eventual entry, and even that is unlikely). Compare Kaplow, 85 Colum L Rev at 536-39 (claiming that concern over delayed entry lies at the "very heart" of the antitrust laws).

${ }_{16}$ Posner, Antitrust Law at 173. This analysis may be incomplete. If the tier has monopoly power, there remains the possible problem of "monopsony," a market of a single buyer and multiple sellers. In a monopsony, the buyer (in this case, or monopolist in the tying good) has market power to extract a favorable price from the competitive suppliers, leading to dislocations in the market.

${ }^{17}$ Id at 172-73. But see Kaplow, 85 Colum L Rev at 525-39 (criticizing the "Chicago School of Antitrust Analysis" and arguing that leverage is possible under certain circumstances). 
monopolist been unable to tie. ${ }^{18}$ The monopolist will be able to charge $\$ 9$ for the computer time and $\$ 1$ for the cards or $\$ 6$ for the computer time and $\$ 4$ for the cards, but she will not be able to charge the high price for both, for the consumer is only willing to pay a total of $\$ 10$ for the combination of the two.

Judge Posner further criticizes the conventional analysis of tie-ins. What is it, he asks, that makes a mimeograph machine and its ink "separate" products, but an automobile and its radiator a single product? Since all products have components, the judicial system could have a "devastating" reach through tie-in prosecutions, because of the lack of a satisfactory test to distinguish tied from single products. ${ }^{19}$ Posner notes that other monopoly laws address attempted monopolization through leverage. Thus, he suggests, tie-in doctrine should be limited to tie-ins that price discriminate-that is, those tie-ins that sell the same product to different customers at different prices even though the cost of sale is the same to each of them. ${ }^{20}$ Judge Bork goes even further, arguing that "we have no acceptable theory of harm done by these phenomena."

But even assuming, as a number of economists do, that a tying monopolist cannot hurt consumers through leveraging or by imposing entry barriers, we might ask why any rational profitmaximizing monopolist would ever tie. If price discrimination were the only rational motivation for a tie, that would seem to be reason enough to prohibit the tie-in. However, price discrimination is not the only reason for a tie. Economists point to several reasons why a monopolist would find a tie-in profitable and why consumers would find them beneficial: ${ }^{22}$ evasion of regulation, ${ }^{23}$

18 See Bork, Antitrust Paradox at 375 (arguing that price discrimination can lead to similar outcomes as competitive industries).

19 Posner, Antitrust Law at 181.

${ }_{20}$ Id at 62, 183. But see Bork, Antitrust Paradox at 380-81.

${ }^{21}$ Antitrust Paradox at 380-81.

22 Id at $372,380-81$.

${ }^{23}$ A seller subject to some sort of price regulation might try to evade that regulation through the use of a tied good in an unregulated market. See Ward S. Bowman, Jr., Tying Arrangements and the Leverage Problem, 67 Yale L J 19, 21-23 (1957); Bork, Antitrust Paradox at 376; Roger D. Blair and David L. Kaserman, Antitrust Economics 383-84 (Richard D. Irwin, 1985). See also Alfred E. Kahn, I The Economics of Regulation 28 n 20 (MIT, 1988) (discussing how public utility companies have evaded profit restraints by paying excessive prices to unregulated affiliates); Richard A. Posner and Frank $\mathrm{H}$. Easterbrook, Antitrust: Cases, Economic Notes, and Other Materials 809 (West, 2d ed 1981) (describing how a gasoline station used a tie-in arrangement to circumvent government price controls on gasoline; the station required consumers who bought gas at the low controlled price to buy a rabbit's foot at an inflated price). Regulation evasion can include price floor evasion. For example, before the deregulation of the airline industry, 
non-discriminatory measurement of use, ${ }^{24}$ economies of scale, ${ }^{25}$ and goodwill. ${ }^{26}$ Even in the case of price discrimination, the firm's gain from the tie comes out of the deadweight loss of monopoly, not from any redistribution from consumers to monopolists. ${ }^{27}$

some airlines offered remarkable package deals on car rentals and the like. Id at $809 \mathrm{n} 8$. See, for example, Robert's Waikiki U-Drive, Inc. v Budget Rent-A-Car Systems, Inc., 732 F2d 1403, 1405 (9th Cir 1984). Nevertheless, a seller would be unlikely to make such a tie mandatory, so though the tie might once have been illegal, see Northern Pacific Railway, 356 US 1, it would not currently be illegal under Jefferson Parish's notion of "forcing." See text accompanying notes 74-82.

Northern Pacific Railway, where a sale of land was tied to a railroad service, may best be explained as an effort to evade a regulatory price that was set too high. But see Kaplow, 85 Colum L Rev at 522 n 26 (cited in note 12) (criticizing the Chicago School's defense of a practice when the underlying motive for the practice is illegal). The resulting regulation of ties to enforce other regulatory restraints is a good example of how regulation must continuously expand jurisdiction to prevent evasion. See Alfred E. Kahn, 2 Economics of Regulation 28-32 (MIT, 1988) (discussing this "regulatory creep").

24 Bork, Antitrust Paradox at 378 (cited in note 10). In measurement-of-use cases (situations where the seller's costs vary with the use her machine receives), a tie-in will simply recover costs of service, rather than act as a mechanism for price discrimination.

${ }_{25}$ Id at 378-79. Economies of scale almost certainly explain the Times-Picayune case, 345 US 594, though the Court in part ruled on the grounds that there was no tie because the morning and evening newspapers sold the same product: the readership "bought" by advertisers. Id at 613. Such reasoning, of course, only demonstrates the dangerous malleability of the "separate product" conception of tie-in law.

${ }_{25}$ Bork, Antitrust Paradox at 379-80. See, for example, the rejected arguments of the defendants in International Business Machines Corp. v United States, 298 US 131, 134 (1936), and Eastman Kodak, 112 S Ct at 2091.

${ }^{27}$ Posner, Antitrust Law at 173-84 (cited in note 10); Bork, Antitrust Paradox at 376378. Kaplow argues that this rationale is an illegitimate one, because price discrimination is illegal under the Robinson-Patman Act. 85 Colum L Rev at 522-23, citing 15 USC § 13 (1982) ( $\$ 2$ of the Clayton Act, amended by the Robinson-Patman Act of 1936, ch 592, 49 Stat 1526). But this is a false argument. The "price discrimination" prohibited by the Robinson-Patman Act should not be equated with what economists call price discrimination, and Kaplow has confused the two different concepts. The economic definition of price discrimination is "selling at a price or prices such that the ratio of price to marginal cost is different in different sales," Posner, Antitrust Law at $62 \mathrm{n}$ 35, while the Robinson-Patman Act only prohibits "price differences" that are unjustified. See FTC v Anheuser-Busch, Inc., 363 US 536, 549 (1960). See Richard A. Posner, The Robinson-Patman Act: Federal Regulation of Price Differences (American Enterprise Institute, 1976).

Ironically, one of the possible benefits of tie-ins given in Jefferson Parish, 466 US at 12-that "[b]uyers often find package sales attractive"-has little economic justification. That buyers find a package sale attractive is no reason for courts to distinguish one tie-in from others. Unless other already-mentioned factors are at work, there is no harm to consumers if a manufacturer offers a choice: buy the goods separately or buy them as a package. Perhaps the Court intended to say that offering a package in addition to the option of taking the goods separately creates no tie-in problem. Id at $12 \mathrm{n} \mathrm{17}$, citing Northern Pacific Railway, 356 US at $6 \mathrm{n} 4$. Another plausible explanation is that the Court was really referring to the sale of two "inseparable" products as a single product, such as a left shoe and a right shoe, and calling such a sale a "package." This ambiguity further illustrates how courts often become confused in their attempts to create a coherent tie-in policy. 
B. Why Would a Dealer Tie Without Economic Interest? Collective Action Problems and Some Cases

In Miller Motors $v$ Ford Motor Co. ${ }^{28}$ and other economic interest cases discussed below, courts have ruled that purported tie-ins were not illegal because the sellers in question did not have an economic interest in the tied product markets. But if there was no economic interest, why would a seller ever choose to tie? Aside from the reasons already mentioned, a seller might choose to tie to resolve a collective action problem. This subsection discusses collective action problems, both in general and in the context of antitrust law, before turning to the collective action problem at the heart of Miller Motors and other economic interest and tie-in cases.

\section{Collective action problems.}

Pollution is a classic example of a collective action problem. Residents of a smog-ridden city might wish to require all drivers to equip their cars with costly emission-control devices in order to reduce pollution. But without an enforced agreement or law, too many car owners will not install the devices voluntarily. The hundreds of dollars spent on any single device will bring at least that much benefit to all residents of the area, yet the individual benefit to any one person will be small. Individuals have an incentive to "free ride" off of their neighbors' devices; Nigel cannot prevent Steve from enjoying the cleaner air that results from Nigel's emission-controlled car. A law requiring cars to have emissions controls removes the option of free riding, and thus everyone is better off. ${ }^{29}$

Through a tie-in, a seller likewise removes certain options from consumers' menu of choices. Therefore, courts assessing the validity of a particular tie-in should ask whether consumers would prefer in advance not to have the option available to them, just as Nigel and Steve surely would have preferred not to be allowed to engage in the self-destructive behavior of polluting.

23252 F2d 441 (4th Cir 1958).

29 This conclusion, of course, assumes that the benefits of the hypothetical environmental statute outweigh the costs of the emission-control devices. 


\section{Collective action problems in antitrust law.}

Collective action problems arise in a number of circumstances in antitrust law, most notably in resale price maintenance cases. $^{30}$ Resale price maintenance is the practice whereby a manufacturer forbids its dealers from reselling its goods below a certain price, to ensure that the dealers will be able to afford to provide services to consumers. Without resale price maintenance, some dealers might attempt to free ride off of other dealers who do provide services. The free riders, because they do not incur the costs of providing services to consumers, can price their products below the prices that dealers who do offer service must charge. A customer could solicit technical advice and information from a full-service dealer, and then make his purchase from a free-riding dealer. The end result is that no dealer will pay the extra cost of providing services.

The Supreme Court at first failed to distinguish resale price maintenance from ordinary price-fixing and declared it and its economic equivalent, exclusive service territories, ${ }^{31}$ per se illegal in Dr. Miles Medical Co. $v$ John D. Park \& Sons Co. and United States $v$ Arnold Schwinn \& Co $^{32}$ After much criticism, the Court reversed Schwinn in Continental T.V., Inc. $v$ GTE Sylvania Inc., holding that exclusive service territories would be decided under the rule of reason. ${ }^{33} \mathrm{~A}$ class of boycott/refusal-to-deal cases also fits within the same paradigm of a manufacturer facing antitrust

3o See the discussion of resale price maintenance in Posner, Antitrust Law at 147-66 (cited in note 10).

31 An exclusive service territory protects a dealer from competition from other dealers within a certain geographic area. A resale price maintenance policy protects dealers from being undersold by other dealers. If anything, exclusive service territories restrict trade further than resale price maintenance; the latter says "Dealer $\mathrm{X}$ may not sell widgets below price $\mathrm{Y}$ in territory $\mathrm{Z}$," while the former says "Dealer $\mathrm{X}$ may not sell widgets in territory $\mathrm{Z}$," thereby preventing even so much as non-price competition.

${ }_{32}$ Dr. Miles Medical Co. v John D. Park \& Sons Co., 220 US 373 (1911) (resale price maintenance); United States v Arnold, Schwinn \& Co., 388 US 365 (1967) (exclusive service territories).

${ }_{33} 433$ US $36,58-59$ (1977). Under the rule of reason, the court performs a factspecific analysis: "The true test of legality is whether the restraint imposed is such as merely regulates and perhaps thereby promotes competition or whether it is such as may suppress or even destroy competition." Chicago Board of Trade $v$ United States, 246 US 231, 238 (1918).

Resale price maintenance, though, is still per se illegal, even though it has no worse an effect than the granting of exclusive service territories. Of course, under current antitrust law, if the manufacturer is also the dealer, it can sell at whatever price it chooses. Robert H. Bork, The Rule of Reason and the Per Se Concept: Price Fixing and Market Division II, 75 Yale L J 373, 429-64 (1966); Posner, Antitrust Law at 160. 
liability for attempting to prevent distributors from free riding off the efforts of other distributors. ${ }^{34}$

3. Collective action problems in tie-in cases: The Miller Motors case.

In Miller Motors, Ford Motor Company "encouraged and aided" the formation of Lincoln-Mercury Dealers Advertising Funds (LMDAs), entities comprised of Lincoln-Mercury dealers and distinct from Ford itself. ${ }^{35}$ To raise money with which to promote Ford's new line of Lincoln-Mercury cars, each LMDA made compulsory assessments of five to sixty dollars on cars provided to dealers by Ford. ${ }^{36}$ The assessments were collected by Ford as part of the price it charged for each car. They were then turned over to the respective LMDAs, which, in turn, spent the money on advertising through the advertising firm of Kenyon and Eckhardt. The advertising firm had no corporate relationship with Ford. ${ }^{37}$ Ford made it clear that it would terminate franchises of dealers who refused to participate in the LMDA. ${ }^{38}$

Why should Ford care if dealers refused to give money to an advertising firm that had nothing to do with Ford? As in the case of the emission-control devices that benefitted all of the city residents regardless of whether or not their own car was equipped with one, the national advertising fund was a benefit to all Lincoln-Mercury dealers, and, by extension, to Ford.

The collective action aspects of Miller Motors are fairly straightforward. Assume that participation in the LMDA was voluntary. Dealers will either choose to fund a LMDA, or they will not. In either situation, Miller Motors will choose not to join the LMDA and to free ride on whatever LMDA contributions other dealers make. If dealers do fund a full-fledged LMDA, Miller has the incentive to cheat rather than let other dealers benefit from its contribution. If Miller alone decides to advertise nationally, its efforts are misplaced, and it will not reap the benefit of its altruism. Thus, Miller will choose not to contribute to a LMDA.

Consider now that each of the other dealers is similarly situated to Miller Motors. For each and every dealer, it is more bene-

3t See, for example, United States $v$ General Motors Corp., 384 US 127 (1966).

35252 F2d at 444.

36 Id at $443-44$.

37 Id at 444.

38 Id at $\mathbf{4 4 5}$. 
ficial to become a free rider and to refuse to contribute to a LMDA. Whether or not the other dealers contribute, it will be more profitable for any single dealer to choose not to contribute: although one marginal dollar of contribution will generate marginal revenues of one dollar, those revenues will be spread among all dealers. Thus, each dealer will choose not to contribute to a LMDA. As a result, both Ford and its dealers are worse off than they would have been if all dealers had joined a LMDA. Each dealer profits less than it would have otherwise, and Ford sells fewer Lincoln-Mercury cars. The dealers could attempt to organize and set up a common pool of advertising, but free-rider problems would remain. The more dealers, the greater the coordination and collective action problem would be. Without any system of enforcement, a nationwide advertising program would be impossible. $^{39}$

Even if dealers are not similarly situated, one need only make the reasonable assumption that some dealers at the margin will find it unprofitable to sell cars without LMDA support. Because of the collective action problem, all of the dealers will refuse to form a LMDA. The optimal strategy for some dealers will be to terminate the franchise and refuse to sell Lincoln-Mercury cars. Fewer dealers will result in less competition, hurting consumers.

Now return to the facts of Miller Motors, in which Ford effectively created a tying arrangement whereby a dealer does not have the option of having a Lincoln-Mercury franchise if it refuses to participate in a LMDA. If Miller Motors refuses to pay into an existing LMDA, it can no longer free ride off of other dealers' contributions, because Ford will terminate its franchise. The tie-

39 One might complain at this point that though Lincoln-Mercury dealers are technically engaged in commerce with Ford, the focus of the analysis and the intent of antitrust laws should be aimed more at the effect on the end consumer, rather than on the level of profit received by intermediaries and manufacturers. The debate on this issue is cut somewhat short by the Supreme Court's decision interpreting Section 4 of the Clayton Act, 15 USC $\S 15$ (1982), in Illinois Brick Co. $v$ Illinois, 431 US 720 (1977). In Illinois Brick, the Court held that, with some exceptions, consumers can sue for damages due to a price-fixing agreement only if they have directly purchased from the alleged wrongdoer. Id at 746-47. Resolving the controversy over Illinois Brick lies beyond the scope of this Comment. Compare, for example, Robert G. Harris and Lawrence A. Sullivan, Passing On the Monopoly Overcharge: A Comprehensive Policy Analysis, 128 U Pa L Rev 269 (1979), with William M. Landes and Richard A. Posner, The Economics of Passing On: A Reply to Harris and Sullivan, $128 \mathrm{U}$ Pa L Rev 1274 (1980). But even if, arguendo, Congress eventually does overturn the "direct purchaser" limitation, the reasoning of this Comment would not be affected. The collective action problem explored here is equally applicable to analysis of harms to consumers as it is to intermediaries. 
in solves the free-rider problem. All dealers pay into a LMDA, and everyone is better off. Once we acknowledge that some dealers will find it unprofitable to continue their franchise without the benefit of the tie-in, we appreciate that the tie-in has a beneficial effect on consumer welfare: there are more Lincoln-Mercury dealers than there would have been without the LMDAs, and consumers have a greater number of choices. ${ }^{40}$

Antitrust law should not deem this tie-in illegal, as the arrangement works for the mutual benefit of all involved: end consumers, dealers, and Ford. Just as Nigel and Steve prefer a law that prevents them from engaging in the self-destructive behavior of polluting, the dealers would prefer to avoid their collective action problem through the foreclosure of the option of not contributing to a LMDA. Indeed, the record in Miller Motors indicates just that. The LMDAs were established immediately following Ford's establishment of a separate Lincoln-Mercury division in 1946, at the unanimous request of the dealers' elected representatives to Ford. ${ }^{41}$ In fact, dealers pressured Ford into threatening to revoke franchises of recalcitrant dealers who refused to contribute to advertising funds. ${ }^{42}$ Also, the record implies that Miller Motors brought its suit challenging its franchise termination for reasons other than the LMDA participation requirement. $^{43}$

\section{Other cases.}

a) Franchising cases. Of course, the Miller Motors scenario is not the only one in which a tying arrangement can solve

40 Note also that the resale price maintenance cases and the Miller Motors case are analytically the same. The manufacturer's interests vis-a-vis the middleman dealer are identical to those of the consumer: both want the cost of distribution to be as low as possible.

The alignment of manufacturer and consumer interests in these cases is important. Not all resolutions of collective action problems promote consumer welfare. For example, a cartel may enter into a price-fixing agreement to solve the collective action problem created by competitive pricing, but such an agreement damages end-consumers; cartel price-fixing is thus per se illegal. Courts should determine whether collective action solutions benefit end-consumers (or classes of end-consumers) and not just manufacturers.

41 Miller Motors, 252 F2d at 443.

42 Id at 445.

43 Quite apart from the LMDA arrangement, the pressures of the auto business created tension between Miller and Ford. In the face of falling demand for cars, Ford increased its sales quotas for its franchisees. At the same time, Miller "was not capable of meeting the keen and ruthless competition which developed .... iller was uncooperative, critical[,] ... and at times abusive, belligerent and threatening." Miller Motors $v$ Ford Motor Company, 149 F Supp 790, 798 (M D NC 1957). 
a collective action problem. A very common collective action problem arises in franchising arrangements, and it too can be solved by a tie-in.

A franchisor licenses franchisees to sell goods, such as fast food. The efforts of any one franchisee will redound to the benefit of all; failures in quality or service of any one franchisee will reflect poorly upon them all. To ensure that individual franchisees will not attempt to free ride off the efforts of the more conscientious franchisees by skimping on the quality of the goods purchased, a franchisor might require, as a condition to granting the license, the purchase of certain items from distributors who have a demonstrable level of quality. The franchisor's requirement is a prime example of a tie-in for which the tying firm has no economic interest in the tied product. ${ }^{44}$

This problem is often stated as being a goodwill issue where the franchisor wants to protect the quality of the franchise brand name. But such a classification defines the issue too narrowly; the franchisees want to be bound to maintain a certain level of quality ex ante. An owner of a Wendy's ${ }^{45}$, in Columbus does not want her reputation to be negatively affected by the shoddiness of a Wendy's in Pittsburgh; nor does the Columbus owner want to be the only one maintaining a relatively high level of quality when the effects of that quality will be dispersed amongst the general reputation of Wendy's restaurants as a whole. Again, the consumers in this case (the franchisees) would like to have the option of buying inferior-quality supplies foreclosed to them.

b) Crawford Transport. Crawford Transport $v$ Chrysler Corp. dealt with Chrysler's vehicle transportation policies. ${ }^{46} \mathrm{Be}$ fore changes in Chrysler policy, transporters dealt directly with Chrysler dealers, soliciting business from them and charging them shipping costs. About eighty carriers shipped Chrysler cars

44 See, for example, Midwestern Waffles, Inc. $v$ Waffle House, Inc., 734 F2d 705, 712 (11th Cir 1984); Keener v Sizzler Family Steak Houses, 597 F2d 453 (5th Cir 1979); Kentucky Fried Chicken Corp. v Diversified Packaging Corp., 549 F2d 368, 377 (5th Cir 1977). The collective action problem remains the same even where the franchisor does have an economic interest in the tied goods, as in Siegel $v$ Chicken Delight, Inc., 448 F2d 43 (9th Cir 1971), demonstrating the risks in emphasizing the words "economic interest," rather than the concept of "economic interest in the tied market." See text accompanying notes 112-114.

${ }^{45}$ Or a McDonald's, or a Blockbuster Video, or an Akbar \& Jeff's Tofu Hut. Nothing in this analysis turns on the nutritional value of a Monterey Ranch Chicken Sandwich.

${ }^{46} 338$ F2d 934 (6th Cir 1964). 
from manufacturing plants to dealers. ${ }^{47}$ Chrysler decided to economize on these transportation costs by using only sixteen carriers, assigned to the dealers by Chrysler, and billing their costs through Chrysler. Chrysler would then bill a "destination charge" to its dealers. ${ }^{48}$ A dealer who bought cars from Chrysler had no choice over the method of transportation despite the existence of a separate automobile transportation market: the very definition of a tie-in. But the centralization and consolidation saved Chrysler (and by extension, its dealers and customers ${ }^{49}$ ) millions of dollars in transportation costs. ${ }^{50}$

Though this case presents no free-riding opportunities, the advantage to the dealers (and to consumers) of collectively acting through Chrysler to arrange transportation is clear. Because of the cost savings, dealers were unambiguously better off because of the tie-in even though they lost the opportunity to choose their own transport company. (It was not the ostensibly-injured Chrysler dealers who brought the suit, but an inferior transport company that lost business under the new arrangement.) The collective action imposed by Chrysler's tie-in gives superior results to consumers compared to a world where such a tie-in is forbidden by antitrust laws and dealers must individually negotiate transportation agreements.

c) Town Sound. Town Sound and Custom Tops $v$ Chrysler Motors Corp. ${ }^{51}$ is similar to Crawford, except that in this case, Chrysler had an economic interest in the tied product, auto stereos. To capture economies of scale, Chrysler began making stereos standard equipment in all of its cars. ${ }^{52}$ Again, this is technically a "tie." Here, however, some consumers might prefer to hold out and insist on a Chrysler package that does not include a car stereo. Whether or not Chrysler decides to tie, there will be free riding. If Chrysler does tie, buyers who want a Chrysler car stereo will free ride off of the benefits obtained by the purchase of stereos by those consumers who buy a car with a stereo they do not want. If Chrysler does not tie, buyers who want a choice will

47 Id at $935-36$

48 Id at 936.

49 And, by extension, other automobile consumers who didn't buy Chryslers, but benefitted from the extra competition Chrysler provided Ford and General Motors at a time when those two dominated the automobile market. Id at 939.

so Id at 937 .

51 959 F2d 468 (3d Cir 1992).

52 Id at $472-73$. 
free ride off of the additional costs imposed upon those who would prefer a Chrysler car stereo. In either situation, Chrysler requires one set of consumers to "subsidize" the tastes of another. But the marketing decision should be dictated by consumers, capable of purchasing Toyotas or Isuzus if Chrysler does not create a desirable automobile package, rather than by antitrust laws prohibiting tie-ins. ${ }^{53}$

d) Thompson. In Thompson $v$ Metropolitan Multi-List, a multilist real estate listing service required brokers to be members of a specific real estate association in order to use the multilist system. ${ }^{54}$ Metropolitan was wholly owned by the DeKalb Board of Realtors, and required members to join either that board or any of a number of other local chapters of the $\mathrm{Na}$ tional Association of Realtors. The professional affiliation provided a code of ethics and mandatory arbitration. ${ }^{55}$ Brokers would be unwilling to join a multilist service if such affiliation were not ensured, because then some brokers could use the multilist service unethically and "steal" a sale or customer without the injured broker having recourse through the realtors' association. If a broker were able to join the multilist service without subscribing to such a code of ethics, it would be able to free ride off of the members who did subscribe. The system would collapse, or, at best, be impaired significantly.

\section{LEGAL HISTORY AND BACKGROUND}

The Sherman ${ }^{56}$ and Clayton Acts ${ }^{57}$ prohibit, among other things, tie-ins. The original concern over tie-ins was that a legitimate monopoly, such as a patent-holder, might "leverage" its market power to extend its monopoly into other markets. ${ }^{58}$ Congress passed Section 3 of the Clayton Act in response to Henry $v$

${ }_{53}$ Note the similarities between this and the case of standard airbags. In the days when airbags were optional, a consumer insisting upon such a feature had to pay hundreds of dollars extra. Due to economies of scale from government-imposed safety standards, airbags come with all cars at a fraction of that cost, even though some consumers would no doubt prefer to buy the cheaper automobile without the airbag.

54 934 F2d 1566 (11th Cir 1991). See also text accompanying notes 120-25.

35 Id at 1570.

56 Sherman Act, 26 Stat 209 (1890), codified as amended at 15 USC $\S 1$ (1988).

${ }^{57}$ Clayton Act, 38 Stat 730 (1914), codified as amended at 15 USC $\$ 14$ (1988). See also Federal Trade Commission Act, 38 Stat 717 (1914), codified at 15 USC $\$ 45$ (1988).

${ }_{58}$ Kurt A. Strasser, An Antitrust Policy for Tying Arrangements, 34 Emory L J 253, 254 (1985). See, for example, Motion Picture Patents Co. $v$ Universal Film Manufacturing Co., 243 US 502, 518 (1917). 
A.B. Dick Co., a Supreme Court decision under the Sherman Act involving a company that sold a mimeograph machine, attaching the condition that it be used only with ink and paper provided by the mimeograph machine maker. ${ }^{59}$ In Motion Picture Patents Co. $v$ Universal Film Manufacturing Co., its first tie-in case after the passage of the Clayton Act, the Supreme Court held that tying unpatented items to a patented machine was illegal. ${ }^{60}$ Since then, the Court has extended the Sherman Act so that it also outlaws tie-ins. ${ }^{61}$

The all-inclusive language of the Sherman Act gives the courts extremely broad discretion. ${ }^{62}$ Though the Supreme Court initially took literally the Sherman Act language condemning "every" restraint of trade ${ }^{63}$ it soon realized that such a prohibition was too broad and began the difficult task of deciding which restraints of trade were unlawful. ${ }^{64}$

\section{A. The Per Se Rule and the Rule of Reason}

To narrow the potentially broad range of antitrust litigation, the Supreme Court established a doctrine under which some contractual arrangements are considered so unreasonable that they are illegal as a matter of law. ${ }^{65}$ These per se classifications are derived by assessing

[t]he probability that anticompetitive consequences will result from a practice and [balancing] the severity of those consequences ... against its procompetitive consequences.

59 224 US 1 (1912). The Dick Court held that defendants' sale of ink and paper to a mimeograph owner constituted contributory infringement of the patent of the mimeograph machine maker. Id at 11-14. See Clayton Act, HR 15657, 63d Cong, 2d Sess (April 14, 1914), in 51 Cong Rec 16144, 16147 (Oct 5, 1914) (remarks of Senator Walsh).

60 US 502,518 (1917).

61 International Salt Co., 332 US at 396.

62 Section 1 of the Sherman Act provides: "Every contract, combination in the form of trust or otherwise, or conspiracy, in restraint of trade or commerce among the several states, or with foreign nations, is hereby declared to be illegal." 15 USC \& 1 (1988). See also Standard Oil Company of New Jersey v United States, 221 US 1, 59-60 (1911); Sullivan and Harrison, Understanding Antitrust and Its Economic Implications $\$ 1.03$ at 6 (cited in note 11), quoting 21 Cong Rec 2460 (1890) (remarks of Senator Sherman).

6 United States v Trans-Missouri Freight Association, 166 US 290 (1897). But see also id at 354 (White dissenting) (criticizing this strict interpretation as an enormous injustice").

st See Standard Oil Company of New Jersey, 221 US at 60-66 (allowing courts discretion in determining whether a restraint on trade was reasonable).

c5 See, for example, United States v Columbia Steel Co., 334 US 495, 522-23 (1948) (noting, as examples of per se violations, price-fixing agreements, refusals-to-deal, and conditioning licenses for patented products on the use of unpatented items). 
Cases that do not fit the generalization may arise, but a per se rule reflects the judgment that such cases are not sufficiently common or important to justify the time and expense necessary to identify them. ${ }^{66}$

Under the per se rule, therefore, a court does not need to analyze whether, given particular market conditions, the behavior in question is indeed anticompetitive. ${ }^{67}$

A plaintiff's failure to state a per se illegal claim is not fatal if she can state a claim under the rule of reason. ${ }^{68}$ Under this approach, the court does not presume illegality. Instead, it inquires into the agreement's actual effects on competition. ${ }^{69}$ Such an examination permits the use of economic analysis to determine the effects of a tie-in, but requires more litigation. Once a plaintiff proves her per se case, on the other hand, a defendant will be liable even if the particular practice is socially beneficial. The Supreme Court has, at times, been reluctant to reclassify practices that it had previously ruled per se illegal as falling within the rule of reason, even when lower courts have found the specific practices procompetitive and beneficial to consumers. ${ }^{70}$

\section{B. The Supreme Court and Tie-ins}

Since the passage of the Clayton Act, the Supreme Court has revisited tie-ins several times. At times, the Court has been especially critical. Justice Frankfurter once wrote, "Tying arrangements serve hardly any purpose beyond the suppression of competition."11 The Court first applied the per se rule to tie-ins in International Salt Co., Inc. $v$ United States, on the grounds that "it is unreasonable, per se, to foreclose competitors from any substantial market."72 However, the Court has since retreated from this severe posture, though not before substantially expanding the reach of tie-in law. ${ }^{73}$

${ }_{68}$ Continental T.V., 433 US at $50 \mathrm{n} 16$.

${ }^{67}$ Jefferson Parish, 466 US at 15-16 n 25.

${ }_{68}$ Id at 17-18; Fortner Enterprises, Inc. v United States Steel Corp., 394 US 495, 499500 (1969) ("Fortner $I^{\prime \prime}$ ).

69 Jefferson Parish, 466 US at 29; Fortner I, 394 US at 500.

${ }^{70}$ Compare, for example, Arizona v Maricopa County Medical Society, 457 US 332 , 351-54 (1982) (disputing the lower court's finding of a procompetitive practice), with Continental T.V., 433 US at 57-59 (rejecting per se illegality in favor of rule of reason analysis for vertical restrictions in the face of "substantial authority supporting their economic utility").

${ }^{71}$ Standard Oil Co. of California v United States, 337 US 293, 305-06 (1949).

72332 US 392, 394, 396 (1947).

${ }^{73}$ See Times-Picayune, 345 US at 608-09 (holding the Clayton Act prohibits tie-ins 
In Jefferson Parish Hospital District No. $2 v$ Hyde, a case involving a hospital's tie of hospital services to anesthesiological services, the Court stood by a modified per se rule for tie-ins. ${ }^{74}$ Because buyers often find package sales attractive, "not every refusal to sell two products separately can be said to restrain competition." ${ }^{75}$ In place of International Salt's strict per se rule, the Court emphasized a more consumer-based standard:

[T] he essential characteristic of an invalid tying arrangement lies in the seller's exploitation of its control over the tying product to force the buyer into the purchase of a tied product that the buyer either did not want at all, or might have preferred to purchase elsewhere on different terms. ${ }^{36}$

The practices in question must involve a substantial volume of commerce to trigger the per se rule. ${ }^{77}$ Also, the Court emphasized that the application of the per se rule should focus "on the probability of anticompetitive consequences." ${ }^{.78}$

when there is a "monopolistic position" in the market for the tying product or the tie affects a "substantial" volume of commerce in the tied product); Northern Pacific Railway, 356 US at 11 (construing the economic power standard from Times-Picayune's "monopoly power" to require only "sufficient economic power to impose an appreciable restraint on free competition"); United States v Loew's Inc., 371 US 38, 45 (1962) ("Even absent a showing of market dominance, the crucial economic power may be inferred from the tying product's desirability to consumers or from uniqueness in its attributes."); Fortner I, 394 US at 504 (stating economic power exists when "the seller has the power to raise prices, or impose other burdensome terms such as a tie-in, with respect to any appreciable number of buyers within the market"). Under Fortner $I$, the mere existence of a tie-in was in and of itself proof of economic power that would make the tie-in per se illegal. Kenneth W. Dam, Fortner Enterprises v. United States Steel: "Neither a Borrower Nor a Lender $B e,{ }^{\prime} 1969 \mathrm{~S}$ Ct Rev 1, 18. The Supreme Court softened this position when the Fortner case came before it a second time. United States Steel Corp. $v$ Fortner Enterprises, Inc., 429 US 610 (1977) ("Fortner II") (holding, despite presence of tie-in, that the plaintiff failed to show the seller had the requisite economic power to effect an illegal tie-in).

74466 US 2 (1983).

75 Id at 11 . But see note 27.

76 Id at 12.

7 Id at 16 ('If only a single purchaser were 'forced' with respect to the purchase of a tied item, the resultant impact on competition would not be sufficient to warrant the concern of antitrust law."). What impact would be significant enough to trigger the application of antitrust law? One hint might come from Fortner I, where the Supreme Court defined the necessary impact as "substantial enough in terms of dollar-volume so as not to be merely de minimis." 394 US at 501. In 1969, the Court deemed $\$ 190,000$ to be substantial enough. Id at 502. Lower courts have disagreed on what is de minimis in this context. Compare Yentsch v Texaco, Inc., 630 F2d 46, 58 (2d Cir 1980) (\$15,000 is probably not substantial enough), with Tic-X.Press, Inc. v Omni Promotions Company of Georgia, 815 F2d 1407, 1419-20 (11th Cir 1987) ( $\$ 10,000$ is more than de minimis).

${ }^{78}$ Jefferson Parish, 446 US at 15-16. 
In a concurrence joined by three other justices, Justice O'Connor sharply criticized the per se rule in the tie-in context and urged the Court to abandon it. She noted that the Court, by its reluctance to rule a tie-in illegal "without proof of market power or anticompetitive effect,"79 and its willingness to allow affirmative defenses to per se violations, ${ }^{80}$ derived no advantage at all from the per se rule. In other words, the doctrine as construed by the majority required much of the time-consuming economic analysis associated with the rule of reason, while still allowing the prohibition of "arrangements that economic analysis would show to be beneficial." J1 Justice O'Connor also mentioned the additional danger of lower courts oversimplifying the per se rule by omitting the necessary economic analysis. ${ }^{82}$

With this new vague hybrid standard somewhere between the per se rule and the rule of reason, the Court punted tie-ins back to the lower courts, leaving the internal contradictions between legal and economic theory largely unresolved.

\section{Controversy Over an Economic Interest Test}

While Jefferson Parish's recommendation that courts focus on the probability of anticompetitive consequences when evaluating tie-ins is as close as the Court has come to offering an explicit threshold for the per se rule, federal appellate courts have developed their own formulae for identifying illegal tie-ins. In Yentsch v Texaco, Inc., the Second Circuit developed one influential test. ${ }^{83}$ To invalidate a tie-in arrangement, Yentsch required proof of five elements: identification of separate tying and tied products; "evidence of actual coercion by the seller that in fact forced the buyer to accept the tied product"; "sufficient economic power in the tying product market" to make coercion possible; "anticompetitive effects in the tied market"; and, finally, "involvement of a 'not insubstantial' amount of interstate commerce in the tied product market." ${ }^{\text {(34 }}$ Other courts use similar rules with only slightly different requirements. Though Yentsch predated Jefferson Parish, the Supreme Court ignored the effort by the

79 Id at 34 (O'Connor concurring).

80 Id at 34 n 1, citing United States $v$ Jerrold Electronics Corp., 187 F Supp 545, 55960 (E D Pa 1960), aff'd per curiam, 365 US 567 (1961).

81 Id at 34 (O'Connor concurring).

82 Id at 34-35.

83630 F2d 46 (2d Cir 1980).

84 Id at 56-57, quoting Fortner I, 394 US at 501. 
Second Circuit-as well as attempts by other circuits-to clarify the tie-in doctrine.

Many circuits have followed Miller Motors ${ }^{85}$ in supplementing their Yentsch-like formulae with an economic interest requirement. ${ }^{86}$ Over time, however, courts gradually distorted the Miller Motors economic interest test to mean something completely different. This trend culminated in a complete rejection of the Miller Motors test by the Second Circuit. ${ }^{87}$

The court in Miller Motors-the first to use what has become known as the economic interest test-referred to the economic interest in the tied product market. ${ }^{88}$ If there is no showing that the tier will or can foreclose competition in the tied product market, then there can be no leverage, and thus no anticompetitive danger, even if the tying party earns additional profit from the tie. For example, in Crawford, Chrysler required dealers to have their cars shipped by a Chrysler-selected dealer. ${ }^{89}$ The Sixth Circuit noted:

[Chrysler] did not seek to invade and dominate the automobile transportation carriers' business. True, Chrysler benefited financially to the extent that it saved millions of dollars in the cost of transportation[,] but it received no direct profits from the transportation carriers. ${ }^{90}$

As in Miller Motors, the economic interest inquiry focuses, as it should, on the tier's interest in the tied product market, and finds an antitrust violation only where the tying seller seeks to "invade and dominate" the tied product market.

Bs For discussion of Miller Motors, see text accompanying notes 35-43.

so See Miller Motors, Inc. v Ford Motor Co., 252 F2d 441, 446-47 (4th Cir 1958); Crawford Transport Co. v Chrysler Corp., 338 F2d 934, 939 (6th Cir 1964); Venzie Corp. $v$ United States Mineral Products Co., Inc., 521 F2d 1309, 1317 (3d Cir 1975); Ohio-Sealy Mattress Manufacturing Co. v Sealy, Inc., 585 F2d 821, 835 (7th Cir 1978); Keener $v$ Sizzler Family Steak Houses, 597 F2d 453, 456 (5th Cir 1979); Roberts v Elaine Powers Figure Salons, Inc., 708 F2d 1476, 1479 (9th Cir 1983); Midwestern Waffles, Inc. $v$ Waffle House, Inc., 734 F2d 705, 712 (11th Cir 1984); Carl Sandburg Village Condominium Association No.1 v First Condominium Development Co., 758 F2d 203, 207-08 (7th Cir 1985); Beard v Parkview Hospital, 912 F2d 138, 141 (6th Cir 1990); Thompson v Metropolitan Multi-List, Inc., 934 F2d 1566, 1579 (11th Cir 1991).

${ }^{87}$ Gonzalez v St. Margaret's House Housing Development Fund Corp., 880 F2d 1514 (2d Cir 1989).

${ }_{88}$ "It is not shown that Ford had any interest in the Kenyon and Eckhardt advertising agency except to obtain effective advertising service from it." 252 F2d at 446.

$8938 \mathrm{~F} 2 \mathrm{~d}$ at 936.

$\infty$ Id at 939 (emphasis added).

92 See Miller Motors, 252 F2d at 446 ("Ford was not using its economic position as an automobile manufacturer to invade and dominate the advertising business.") (emphasis 
In most tying arrangements, the economic interest component is not in controversy, "because the seller of the tying product is also the seller of the tied product." however, the seller of the tying product is not the seller of the tied product-a classic example involves a franchisor who requires a franchisee to purchase supplies or equipment from a specified independent supplier. ${ }^{93}$ Here the economic interest test properly exonerates the franchisor of an illegal tie-in charge. Indeed, under a common formulation of the economic interest requirement, the Seventh Circuit has held that "an illegal tying arrangement will not be found where the alleged tying company has absolutely no economic interest in the sales of the tied seller, whose products are favored by the tie-in." ${ }^{\text {94 }}$ Economic interest requires more than that the seller receive profit from the tying arrangement as a whole. ${ }^{95}$ Rather, there must be "some form of economic interest in the sale of the tied product, such as the receipt of a commission or rebate." ${ }^{96}$

Certain courts, however, have apparently ignored the original purpose of the economic interest test-the prevention of extension of monopoly power into new arenas-without explaining why any liability should attach when a tying seller has only an indirect economic interest in the second market. The first case to make this misreading was Moore $v$ Jas. H. Matthews \& Co., where a court found an "economic interest" in commissions on tied product sales. ${ }^{97}$ Moore cites Venzie Corp. $v$ United States Mineral Products Co., Inc. ${ }^{98}$ for the proposition that a commission constitutes an economic interest. But what Venzie actually stated was that not receiving a commission was an indication

added).

In Beard, 912 F2d 138, the Sixth Circuit confirmed that it, unlike the Second Circuit, does not view the economic interest test as invalidated by Jefferson Parish. The court found that the economic interest rule, as understood by Crawford, was "consistent with the fundamental antitrust policy opposing the use of market power in one part of the economy to acquire power in another part and one to which we are bound as the rule of this circuit." Id at 143 (footnote omitted).

${ }_{92}$ Carl Sandburg, 758 F2d at 208, citing Robert's Waikiki U-Drive, Inc. $v$ Budget Rent-A-Car Systems, Inc., 732 F2d 1403, 1407 (9th Cir 1984).

${ }_{93}$ See, for example, Midwestern Waffles, Inc., 734 F2d at 710; Kentucky Fried Chicken, 549 F2d at 373.

${ }_{94}$ Carl Sandburg, 758 F2d at 207.

95 Robert's Waikiki U-Drive, Inc. v Budget Rent-A-Car Systems, Inc., 491 F Supp 1199, 1209 (D Hawaii 1980), aff'd, 732 F2d 1403 (9th Cir 1984); Carl Sandburg, 758 F2d at 208.

${ }_{96}$ Carl Sandburg, 758 F2d at 208.

${ }_{97} 550$ F2d 1207, 1216 (9th Cir 1977).

${ }_{98} 521$ F2d 1309 (3d Cir 1975). 
that there was no economic interest; it is certainly not clear that Venzie held the inverse of that statement to be true. ${ }^{99}$ Indeed, Venzie uses the same "invade and dominate" language found in Miller Motors and Crawford to inform its own definition of economic interest. ${ }^{100}$ Nonetheless, following Moore, courts have allowed increasingly attenuated links to satisfy the economic interest test. ${ }^{101}$

While many circuits continue to apply the indirect economic interest requirement mechanically, the Second Circuit is the first to have rejected it wholesale. ${ }^{102}$ In Gonzalez $v$ St. Margaret's House Housing Development Fund Corp., a group of tenants sued St. Margaret's, a nonprofit housing facility partially subsidized by the U.S. Department of Housing and Urban Development. ${ }^{103}$ The facility assessed residents a fee to cover a mandatory daily meal plan. In dismissing the tenant's antitrust claim, the district court said: "Because defendant has no economic interest in the sale of the tied product, an element essential to a claim for illegal tying is lacking." 104 The Second Circuit vacated and remanded, refusing to implement an economic interest test.

The Second Circuit observed in Gonzalez that the rationale most commonly offered for imposing the economic interest test is to prevent the risk that "the tying seller will acquire market power in the tied-product market."105 But, the court claimed, Jefferson Parish implicitly rejected the economic interest requirement because it "focused primarily on the anticompetitive effect of tying arrangements," rather than on the seller's market power. ${ }^{106}$ The Second Circuit may have believed that, had it adopted the economic interest requirement, it would have weakened the rule that tying is per se illegal. ${ }^{107}$ In making this judgment,

99 Id at 1317.

100 Compare Venzie, 521 F2d at 1317, with Crawford, 338 F2d at 939, and Miller Motors, 252 F2d at 446.

${ }^{101}$ See, for example, Roberts $v$ Elaine Powers Figure Salons, Inc., 708 F2d 1476, 1480 81 (9th $\mathrm{Cir}$ 1983) (claiming a franchisor potentially had an economic interest in the bookkeeping firm which it required franchisees to use); Thompson, 934 F2d at 1579 (finding a possible economic interest in the services provided by national and state real estate associations to a local branch).

102 See Note, 58 Fordham L Rev 1353 (cited in note 8); Casenote, 63 Temple L Rev 595 (cited in note 8).

103880 F2d 1514, 1515 (2d Cir 1989).

104 Id at 1516.

105 Id at 1517.

106 Id, citing Jefferson Parish, 466 US at 14-15.

107 The Gonzalez court noted that "[i]t does not seem [ ] that a majority of the Supreme Court has as yet cut back on the application of tie-in doctrine by incorporating the 
however, the court did not acknowledge the Supreme Court's statement in NCAA $v$ Board of Regents that per se rules may require considerable economic analysis "before the evidence justifies a presumption of anticompetitive conduct."108

Alternatively, the Gonzalez court suggested that St. Margaret's might, in fact, have had an economic interest in the meal program. Yet while St. Margaret's did receive money for providing the meal service, it not only did not earn a profit on the service-federal regulations forbade such profit-but it actually operated the meal plan at a loss, charging the residents less for the meal program than what it paid to the outside contractor. ${ }^{109}$ The Gonzalez court seems simply to have been uncomfortable finding that there was a "lack of 'economic interest' in a situation where the same party actually sold the tying and the tied product directly to the consumer."110 Thus, merely conveying payments as a middleman barred St. Margaret's from claiming that it had no economic interest.

Gonzalez thus stands for the twin propositions that: (1) Jefferson Parish casts serious doubt on the validity of an economic interest requirement for illegal tie-ins; and (2) even if the economic interest inquiry survives Jefferson Parish, the most attenuated of financial interests can constitute an "economic interest." In effect, these two propositions merge into one, for if an interest as insubstantial as that of St. Margaret's can represent an "economic interest," it would seem that no tying arrangement could be protected by the economic interest test. In virtually any tie-in there is a remote interest of some sort. If there were no economic benefit to the tier for tying, why would the tier choose to tie in the first place? ${ }^{111}$

[economic interest test]." Id at 1517.

${ }^{108} 465$ US 85, 104 n 26 (1984). See also Broadcast Music, Inc. $v$ Columbia Broadcasting Systems, Inc., 441 US 1, 19 (1979) (joint selling arrangement by holders of copyrights on musical compositions is not a per se restraint of trade).

${ }^{109}$ Gonzalez, 880 F2d at 1515.

110 Id at 1517.

111 "Economic benefit" in economic theory does not necessarily mean wealth-maximizing in the case of an individual or non-profit corporation. In the Gonzalez scenario, a nonprofit enterprise might achieve intangible, or "psychic," economic benefit from the meal plan. In an earlier challenge to the meal plan, the district court found that:

The specified purposes of the meal plan were to ensure proper nutrition, encourage social interaction and a sense of community, and allow management to identify residents' health problems as they arise.

Gonzalez v St. Margaret's House Housing Development Fund Corp., 668 F Supp 187, 189 (S D NY 1987), aff'd 848 F2d 391 (2d Cir 1988) (per curiam). 
The Second Circuit's willingness to view St. Margaret's insignificant financial stake in the meal plan as an economic interest is the inevitable result of the gradual distortion of the economic interest test. In Miller Motors and Crawford, the courts used a definition of "economic interest" that properly concentrated on the motivations behind the test-whether the plaintiff was attempting to invade and dominate the tied product market. A court applying Moore's superficial understanding of the words "economic interest," rather than the reasoning behind Crawford's use of the test, ${ }^{112}$ could have found in Miller Motors that Ford had an economic interest in Kenyon and Eckhardt's advertising if Ford received an unrelated discount for the volume of advertising purchased. Such an attenuated finding of economic interest may seem implausible, but the Gonzalez court did something similar when it suggested that St. Margaret's might have had an economic interest in the meal plan because it actually sold it. ${ }^{113}$ In the broadest definition of the term, everyone has an economic interest in the goods they tie. ${ }^{114}$

\section{The ECONOMIC INTEREST TeST: PROBLEMS AND SOlUtions}

This Section examines how the Miller Motors test lost its moorings, resulting in the rejection of the economic interest test in Gonzalez. It proposes both a return to the Miller Motors invade-and-dominate standard and an expansion of this standard to exclude other types of beneficial tie-ins from the harsh per se rule. Subsection A assesses how Miller Motors might come out under the current version of the economic interest test, thereby demonstrating how distorted the doctrine has become. Subsection B critiques Gonzalez's rejection of the economic interest test. Subsection C critizes the Moore version of the economic interest requirement. Subsection $D$ finds that the invade-and-dominate standard fits comfortably within the Jefferson Parish framework.

112 Moore's mistake resembles the improper analogies drawn by the Supreme Court in the context of resale price maintenance. See Posner, Antitrust Law at 164-65 (cited in note 10).

113 Gonzalez, 880 F2d at 1515, 1517.

114 Some courts may be using the economic interest test as a proxy for a goodwill defense. As we saw earlier, protecting goodwill in a manufacturer-dealer relationship is just another form of the collective action problem. See text accompanying notes 44-45. Goodwill is a legitimate reason for creating tie-ins but is not a defense to a charge of illegal tying. Standard Oil Co. of California v United States, 337 US 293, 306 (1949) ("The only situation [ ] in which the protection of goodwill may necessitate the use of tying clauses is where specifications for a substitute would be so detailed that they could not practicably be supplied."). 
Finally, subsection $\mathbf{E}$ argues for an extension of the invade-anddominate standard to other tie-in cases, using International Salt to examine the implications that such an expansion would have.

\section{A. Miller Motors and Today's Economic Interest Test}

There is no economic reason to declare the Miller Motors tiein illegal. ${ }^{115}$ It benefits both seller and buyer, and even the end consumer; indeed, the Fourth Circuit invented the economic interest test in order to exonerate Ford..$^{116}$ But such a tie-in would be found per se illegal under the Second Circuit's understanding of the economic interest test in Gonzalez: Ford Motors coerced individual dealers to buy advertising from a third party, foreclosing a substantial amount of interstate commerce in the tied product market.

The Miller Motors court probably viewed the economic interest test as a way to segregate "bad" tie-ins from "good" tie-ins. Even if Kenyon and Eckhardt were a wholly-owned subsidiary of Ford, Miller Motors might still have reached the same result because the court found that "substantial advantages inured to the dealers through the device of a single advertising program." in Miller Motors reaches the right result in this case. Ford had no interest in the tied market of advertising; it had no desire or ability to invade and dominate the advertising market, as the test originally required.

This indicates that the current economic interest test-which amounts to an "indirect economic interest" test-is not the optimal legal approach. Assume, for instance, that Kenyon granted Ford a discount for steering the LMDA business to it. This would be even more beneficial to both Ford and its consumers (dealers),

115 For that matter, one might question whether even to call the practice in Miller Motors a tie-in. Ford could have achieved the same result by simply raising the price of its cars, rather than adding a separate surcharge, in which case Miller Motors could have no complaint. So why did Ford segregate the advertising costs? The record does not indicate. Perhaps Ford could not have effectively internalized the price of the IMDA fund into the automobile; there were twenty separate LMDA funds run by dealers' associations, and their assessments varied greatly. Miller Motors, $252 \mathrm{~F} 2 \mathrm{~d}$ at 444 . Ford might have run afoul of price-discrimination laws if it had charged different prices for the same automobile. Though this may not be an entirely satisfactory explanation, it illustrates the problems that arise in antitrust when judges try to second-guess business decisions. See generally Easterbrook, 76 Georgetown L J 305 (cited in note 9).

116252 F2d at 446.

117 Id. Note, however, that actual economic benefit would be quite irrelevant under a pure per se rule. 
for they would receive the same services at a lower cost. But this benefit would be an indirect economic interest if, as indeed was the case, Ford did other business with Kenyon. ${ }^{118}$ Consequently, the current test would prohibit the arrangement.

A court applying either a "direct" or "indirect" economic interest test without recognizing the "invade and dominate" standard would also fail to distinguish the counterfactual case in which Ford does own Kenyon, even though the economic result is indistinguishable from the case where Ford has no economic interest in the advertising agency. ${ }^{119}$ Ford might have tried to integrate vertically by having in-house advertising-this, too, would be mutually beneficial, but would be considered a direct economic interest. Thus, the Moore indirect economic interest test is not a good device for sorting the "good" tie-ins from the "bad"-but neither is a test that focuses solely on the direct economic interest of the seller. Only a test that requires the seller to have an intention to invade and dominate the tied product market would reach the right result.

The failings of the Moore test can be seen first-hand in Thompson $v$ Metropolitan Multi-List, Inc. ${ }^{120}$ There, Metropolitan required brokers wishing to use its multi-listing real estate service to be a member of a local branch of the National Association of Realtors, whose members subscribed to a common code of ethics-a practice somewhat akin to the Martindale-Hubbell directory requiring lawyers listed within to be a member of the bar. ${ }^{121}$ Metropolitan used this tie-in to avoid the free-riding problems that would result if non-member brokers could "steal" customers from member brokers without fear of violating the code of ethics or being sanctioned by the association. ${ }^{122}$

Using an "absolutely no interest" variation of the economic interest test, the Eleventh Circuit found enough economic interest to preclude summary judgment for the defendants. Its reasoning: subscribers to the multi-listing services paid $\$ 175$ in annual dues to the local realtors' association. In turn, the realtors' asso-

118 The record is unclear whether Ford received any sort of volume discount for the work done by Kenyon.

119 In Miller, each dealer association "was free to select its own advertising counsel, but all ... chose the firm of Kenyon and Eckhardt because it was doing the [LincolnMercury] institutional advertising." 252 F2d at 444. In short, the dealers' choice of an advertising firm was effectively dictated by Ford.

120934 F2d 1566 (11th Cir 1991).

121 Id at 1570.

122 See text accompanying notes 54-55. 
ciations paid a portion of those dues to state and national realtors' associations of which the DeKalb Board of Realtors, which owned Metropolitan, was a dues-paying local branch. ${ }^{123}$ The resulting pennies of benefit that could be attributed to Metropolitan represented enough of an economic interest for the Eleventh Circuit to impose potential liability.

In a circuit that might consider the Miller Motors or Thompson tie-ins illegal, a company in the position of Ford could try to avoid tie-in prosecution altogether by simply charging more for car dealerships and not charging separately for the advertising. ${ }^{124}$ But while charging a higher price would not be illegal, it may be inefficient, because Ford would have less input from the dealers' associations as to advertising, and coordinating local and national campaigns would be more difficult. Furthermore, a court such as Gonzalez might very well try to unravel the transaction to find the tie-in of advertising. Indeed, the Thompson court seemed to indicate that it would have done just that had Metropolitan structured itself to avoid the third-party tie-in. ${ }^{125}$ Alternatively, Ford could have foregone franchising and vertically integrated its dealerships into the larger firm. The vertical integration would be judged under the rule of reason, ${ }^{126}$ even though vertical integration and tying arrangements constitute "alternate means of obtaining precisely the same results" for many monopolists. ${ }^{127}$ Thus, the prohibition against tie-ins might only deflect a firm from a more-efficient illegal practice to a legal one that offers consumers the same options, but at a higher cost. ${ }^{128}$

Under the invade-and-dominate standard, however, a court could recognize the good chance that the tie-in is procompetitive, and thus subject to the rule of reason rather than the per se rule. ${ }^{129}$ In practice, this would enable Ford to introduce evi-

123934 F2d at 1579.

${ }^{224}$ Metropolitan made precisely this argument, to no avail, in the Eleventh Circuit. Id at 1575.

${ }^{125}$ Id at 1576-78.

${ }_{126}$ Brown Shoe Co. Inc. $v$ United States, 370 US 294 (1962). But see Ford Motor Co. $v$ United States, 405 US 562 (1972) (proof of significant foreclosure and industry concentration is enough to create prima facie case).

${ }^{127}$ See Roger D. Blair and David L. Kaserman, Vertical Integration, Tying, and Antitrust Policy, 68 Am Econ Rev 397, 401 (1978).

${ }_{123}$ Id. See also Posner, Antitrust Law at 178 (cited in note 10).

129 Miller Motors, 252 F2d at 446-47. At least one commentator has suggested that a per se legality rule would be preferable in many cases to a rule of reason. Easterbrook, 76 Georgetown $\mathrm{L} J$ at $310-11$ (cited in note 9). 
dence that its tie-in is intended to resolve the collective action problem. Winning summary judgment would be more difficult. Although resolving the collective action problem is a rational explanation for Ford's behavior, presenting this abstract theory alone is probably not enough to support a summary judgment under the current Supreme Court antitrust doctrine presented in Eastman Kodak Co. $v$ Image Technical Services, Inc. ${ }^{130}$ But a court using the proper formulation of the economic interest test would note that the plaintiff failed to show that Ford was attempting to invade and dominate the advertising business, and could dismiss the case on a summary judgment motion. ${ }^{131}$

The economic interest test, like any threshold definition, is only useful if it is an effective way of sorting good from bad "tieins." A definition that is over- or under-inclusive will result in mischaracterizations. As the Miller Motors example shows, the economic interest test can be underinclusive. Had Ford chosen to run the advertising campaign internally, the economic interest test would not have protected it-even though the risk that Ford would monopolize the advertising industry was nonexistent, and even though Ford's practices were procompetitive. Charging a higher price would not violate tie-in laws, but might have created inefficiencies, as Ford would not have been able to pass on regional advertising costs in the areas of the country that had more intensive campaigns.

\section{B. Where Gonzalez Went Wrong}

The Second Circuit did not adequately support its rejection of the economic interest test in Gonzalez. ${ }^{132}$ Although Gonzalez mentioned that the economic interest test addresses the fear of leverage, and noted Jefferson Parish's concern over the impairment of competition in the tied market, ${ }^{133}$ the court failed to indicate why it necessarily follows that a defendant who ties without an

130112 S Ct 2072, 2083 (1992) (“[Matsushita Electric Industrial Co., Ltd. v Zenith Radio Corp., 475 US 574 (1986)] did not hold that if the moving party enunciates any economic theory supporting its behavior, regardless of its accuracy in reflecting the actual market, it is entitled to summary judgment.").

${ }^{131}$ This is a somewhat different question from whether a prerequisite to liability should be the seller having sufficient market power in the tying product market to successfully dominate the tied market, which is an issue beyond the scope of this Comment. See discussion and sources cited in Town Sound and Custom Tops, Inc. v Chrysler Motors Corp., 959 F2d 468, 482-85 \& n 23 (3d Cir 1982) (discussing the controversy over whether to require market power in the tying product market).

$132880 \mathrm{~F} 2 \mathrm{~d} 1514$.

133 Id at 1517. 
economic interest should be subject to the per se rule. The per se rule, as the Supreme Court has said, is meant to apply to a category where it is so probable that the arrangement in question violates antitrust law that it is not worth judicial effort to inquire further into individual cases for possible exceptions. ${ }^{134} \mathrm{~A}$ practice that presents no danger of leverage could hardly fall into such a category. Ironically, Gonzalez's confusion over the per se rule for tying validates Justice O'Connor's fears about misapplication of the rule in the tying context. ${ }^{135}$ Gonzalez implies that imposing an additional threshold to reach the per se rule would "cut back" on the application of tie-in doctrine. ${ }^{136}$ But despite its name, the per se rule is no longer an absolute in tying cases. If the threshold of the economic interest test makes sense, it does not weaken the per se rule. ${ }^{137}$ Rather, it improves the accuracy of the rule by increasing the chances that the cases it covers are indeed so likely to be anticompetitive that further inquiry is unnecessary.

\section{The Moore Economic Interest Test In Practice Today}

Had the Second Circuit taken the analysis in Gonzalez a step further, it could have demonstrated that there is little correlation between whether the tier has an indirect economic interest in the tied market and whether the tie-in should be illegal. In Miller Motors, it was economically irrelevant whether Ford had or had not vertically integrated with the Kenyon advertising agency, but this seems a poor thing to have a case turn on. Should Miller Motors mind whether it is Ford or Kenyon that gets paid for advertising?

Part of the problem arises from Moore's vague understanding of "economic interest," the scope of which can be as broad as courts want, depending on how direct or indirect the interest

134 Continental T.V., Inc. v GTE Sylvania Inc., 433 US 36, 50 n 16 (1977).

135 "[T] law because it appears to invite lower courts to omit the analysis of the economic circumstances of the tie that has always been a necessary element of tying analysis.".Jefferson Parish, 466 US at 34-35 (O'Connor concurring).

136 Gonzalez, $880 \mathrm{~F} 2 \mathrm{~d}$ at 1517.

${ }^{137}$ Note, 58 Fordham $L$ Rev at 1362 (cited in note 8), makes the same mistake as Gonzalez. The claim that the per se rule without an economic interest test simplifies analysis is false because the defendant can rebut the presumption by showing the tie to be beneficial, and the court will engage in the same sort of inquiry as it would were the per se rule weaker. The claim is only true when no rebuttal is allowed. Indeed, even under Gonzalez, a court must make threshold inquiries to determine whether a tie is per se illegal. $880 \mathrm{~F} 2 \mathrm{~d}$ at 1516. 
is. ${ }^{138}$ Yet many other courts share Moore's unprecedented and unsupported view of what constitutes economic interest. ${ }^{139}$

Perhaps courts use the vagueness of Moore's economic interest approach to get around the per se rule because the existing rule also does a poor job of distinguishing good tie-ins from bad. Judges might be using a shifting economic interest test to avoid declaring efficient tie-ins illegal under the per se rule. ${ }^{140}$ If so, this situation is not without precedent. Judge Bork has suggested that the threshold inquiry of whether one good or two goods are being sold is really a poor attempt by courts to exclude efficient tying arrangements from antitrust liability. ${ }^{141}$

If judges are indeed using a shifting economic interest test as a filter for beneficial tie-ins, what are the implications? For individual cases, judges might be attempting-unsuccessfully-to avoid unjust results. They are using what might be a bad rule to avoid applying another bad rule. At the same time, though, they create inconsistent precedents that have little or no predictive value for parties. This lack of certainty will lead to more litigation, ${ }^{142}$ which, in turn, could lead to other unjust results. For example, sellers might be just as reluctant to engage in beneficial tie-ins under a shifting test as under an over-inclusive per se rule. In this context, perhaps the economic dislocation from the simpler per se rule would be preferable to the legal and economic dislocation from the inconsistent application of Moore's version of the economic interest test. ${ }^{143}$ Better than either option, however, would be to devise a more coherent system.

\section{The Economic Interest Test and Supreme Court Doctrine}

The Supreme Court has come a long way since it declared that tie-ins "serve hardly any purpose beyond the suppression of competition." 144 Now it admits that "there is nothing inherently

$138550 \mathrm{~F} 2 \mathrm{~d}$ at 1216.

139 See, for example, Thompson, 934 F2d at 1579.

140 One commentator suggests that this is the rationale behind Venzie. Casenote, 63 Temple L Rev at 605 \& $\mathrm{n} 81$ (cited in note 8).

${ }_{141}$ Bork, Antitrust Paradox at 370-71 (cited at note 10). See, for example, TimesPicayune, 345 US 594, and text accompanying note 21.

142 Richard A. Posner, Economic Analysis of Law § 20.2 at 540-42 (Little, Brown, 4th ed 1992).

163 See, for example, Easterbrook, 76 Georgetown $L J$ at 306 (cited in note 9) (noting that judges and juries are poor decision makers when it comes to judging the competitive effects of complex business practices).

14 Standard Oil, 337 US at 305-06. 
anticompetitive about packaged sales."145 The Court has narrowed tie-in doctrine somewhat, but elements of the per se illegality rule remain. ${ }^{146}$ Thus, one needs to consider what it is about tie-ins that still concerns the Court. Jefferson Parish is the most recent case to explore tie-in doctrine fully.

While Gonzalez found it telling that there was no requirement of economic interest in Jefferson Parish, ${ }^{147}$ a more plausible reason that the Supreme Court did not directly address the economic interest issue is the lack of a finding of a separate product market for anesthesiologists. ${ }^{148}$ Indirect economic interest, as in many tie-in cases, was not at all in dispute. The hospital had a financial interest in its anesthesiologists. A close reading of Supreme Court doctrine finds not only that Jefferson Parish would condone an economic interest requirement, but that it would prefer Miller Motors's emphasis on the tied product market to Moore's implicit focus on indirect financial interest in the sale. Indeed, the Court ruled for the defendant because "there has been no showing that the market as a whole has been affected at all" by the tie-in. ${ }^{149}$

Recall that the Jefferson Parish Court's main concern was "the probability of anticompetitive consequences." In a footnote, the Court cited language in Justice White's dissent in Fortner Enterprises, Inc. v United States Steel Corp. ("Fortner I") that suggests the Court's support for the Miller Motors emphasis on the tied product market:

[T]he fundamental restraint against which the tying proscription is meant to guard is the use of power over one product to attain power over another, or otherwise to distort freedom of trade and competition in the second product. This distortion injures the buyers of the second product, who because of their preference for the seller's brand of the first are artificially forced to make a less than optimal choice in the second .... In addition to these anticompetitive effects in the tied product, tying arrangements may be used to evade price control in the tying product through clandestine

145 Jefferson Parish, 466 US at 25.

146 Id at 32 (Brennan concurring) (claiming that per se illegality is "settled statutory interpretation" that only Congress can modify).

147 Gonzalez, 880 F2d at 1517.

148 See Jefferson Parish, 466 US at 18-25.

149 Id at 31 .

150 Id at 15-16. 
transfer of the profit to the tied product; they may be used as a counting device to effect price discrimination ....

The Court does recognize possible harms from tying, apart from the foreclosure of competitors, such as regulation evasion and price discrimination. But in the end, "any inquiry into the validity of a tying arrangement must focus on the market or markets in which the two products are sold, for that is where the anticompetitive forcing has its impact." or regulation evasion alone is not enough to ban a tie-in; there must be an anticompetitive effect in the tied product market. Again:

[T] he law draws a distinction between the exploitation of market power by merely enhancing the price of the tying product, on the one hand, and by attempting to impose restraints on competition in the market for a tied product, on the other. When the seller's power is just used to maximize its return in the tying product market ... the competitive ideal of the Sherman Act is not necessarily compromised. ${ }^{153}$

However, to permit that power to be used "to impair competition on the merits in another market" would be to condone "the existence of power that a free market would not tolerate."154 Not only does Jefferson Parish focus attention on the tied product market, it says that the Sherman Act does not prohibit a seller from using its power to maximize its return in the tying product market rather than to restrain trade in the tied product market. This emphasis is precisely what the invade-and-dominate standard aims for. An indirect economic interest is no more than an attempt by the seller to "maximize its return in the tying product market," gal per se. Furthermore, where there is no attempt to invade and dominate the market, there is no anticompetitive effect; where there is no anticompetitive effect on the tied product market, the tie should be deemed legal. ${ }^{156}$

151 Id at 13 n 19, quoting Fortner I, 394 US at 512-14 (White dissenting) (footnotes omitted).

${ }^{152}$ Jefferson Parish, 466 US at 18 (emphasis added).

253 Id at 14 (emphasis added) (citations omitted). See also Beard, 912 F2d at 142.

${ }^{154}$ Jefferson Parish, 466 US at 14, 15, quoting Fortner II, 429 US at 617.

155 Id at 14.

156 Gonzalez cites Parts and Electric Motors, Inc. v Sterling Electric, Inc., 826 F2d 712, 718 (7th Cir 1987), for the proposition that Jefferson Parish does not endorse an economic interest test because of the following language: 
E. Solutions: Returning To and Expanding the Invade-andDominate Standard

Jefferson Parish does not mandate the standard proposed by this Comment. After all, if it did, the Court would have adopted an invade-and-dominate standard for tie-in cases across the board. Still, the invade-and-dominate standard is consistent with Court doctrine, and, in fact, is best suited to reach results the Court would find desirable. If antitrust tying doctrine is meant to prevent extension of monopoly power, this would seem to justify such an economic interest test. If the real danger in tying is that it helps extend monopoly power, and if there is no interest in the tied product market, then there is no danger. A congressional policy reflecting the "great concern about the anticompetitive character of tying arrangements" hardly justifies applying the Clayton Act to tie-ins that cannot be proven to be anticompetitive. ${ }^{157}$

If the economic interest test were reformulated to the original definition of "invade and dominate," it would nicely push most tie-ins to a rule of reason analysis, or result in a dismissal on summary judgment motion. In this sense, Moore got it precisely backwards. Rather than using the economic interest test to bludgeon defendants who have an indirect economic interest, courts should expand the economic interest test to require a showing that the defendant seeks to "invade and dominate" the tied product market for a plaintiff's case to survive a summary judgment motion. Though such a standard raises the antitrust hurdle for plaintiffs, it is an easier burden to meet than the Court's standard for attempted monopolization cases under Section 2 of the Sherman Act. ${ }^{158}$

The tying seller may be working toward a monopoly position in the tied product and, even if he is not, the practice of tying forecloses other sellers of the tied product and makes it more difficult for new firms to enter that market.

Jefferson Parish, 466 US at 13 n 19, quoting Fortner I, 394 US at 513 (White dissenting). This reading of the White dissent is too strong. Where there is no attempt to invade the tied product market, there is no foreclosure of competition. One casebook on antitrust comments:

The producer of the tying product has no incentive to disturb the structure of the tied-product market so long as the producers of the tied product are efficient and competitive, for he wants to minimize the cost of that product .... The monopolist will welcome competition in production of the tied product.

Posner and Easterbrook, Antitrust at 807 (cited in note 23).

${ }^{157}$ Jefferson Parish, 466 US at 10.

158 See Spectrum Sports, Inc. v McQuillan, 113 S Ct 884, 890-91 (1993) (holding that a monopolization claim under $\S 2$ of the Sherman Act requires both a specific intent to 
International Salt ${ }^{159}$ illustrates the usefulness of extending the invade-and-dominate standard. International Salt owned a patent on a machine that processed rock salt. It conditioned the lease of the machine on a promise by the machine's lessees to purchase salt from it. ${ }^{160}$ As a result, International Salt obtained a four-percent share of the relevant salt market. ${ }^{161}$ The Court ruled the tie-in per se illegal, ${ }^{162}$ without inquiring into how much of that market share was due to the tie, and without a determination that the four-percent share might cause monopoly problems. The Court simply argued that "[t] he volume of business affected by these contracts cannot be said to be insignificant or insubstantial." 163 It did not consider whether there was any effect on the market as a whole, noting merely that "the tendency of the arrangement to accomplishment of monopoly seems obvious." "164

Yet, users of the salt-processing machine comprised only a small portion of the rock-salt market. International Salt had no intent to invade and dominate the salt market, and could not be said to have any economic interest in the tied product market. Applying Jefferson Parish and an invade-and-dominate standard, the International Salt tie-in would not be per se illegal. The tie-in could still be analyzed under the rule of reason to explore whether International Salt had engaged in price discrimination with anticompetitive effects.

Section I identified several other legitimate reasons why a seller might engage in a tie-in that was beneficial. When the tiein is for purposes of non-discriminatory measurement of use, preserving goodwill, or taking advantage of economies of scale, the tying firm is not attempting to invade and dominate the tied product market, nor is it engaging in practices that harm consumers or competition. ${ }^{165}$ The invade-and-dominate standard would exclude many of these innocuous tie-ins from per se illegality.

monopolize and a "dangerous probability" of achieving market power).

159332 US at 394. See also Bork, Antitrust Paradox at 367-69 (cited in note 10); John

L. Peterman, The International Salt Case, 22 J L \& Econ 351 (1979).

160332 US at 393-94.

161 Peterman, 22 J L \& Econ at 351.

362332 US at 396.

163 Id at 386.

16 Id at 396.

165 See text accompanying notes 22-27. 


\section{CONCLUSION}

In Miller Motors, Ford used a tie-in to solve a collective action problem. The Fourth Circuit recognized that traditional concerns over leverage did not apply because Ford was not attempting to dominate the advertising market. The Court thus excluded the tie-in from the per se rule on an economic interest theory. Nothing economic turns on whether Ford had a direct or indirect economic interest in the advertising agency. The tie-in is equally innocuous in either situation. Unfortunately, by characterizing Miller Motors's "invade and dominate" approach as an "economic interest" test, other courts have misunderstood the point of the case and have whittled the economic interest test to nothing. As a result, other attempts to avoid the collective action problem, as in Thompson, have resulted in potential legal liability; perfectly harmless tie-ins could not command a successful summary judgment motion. A proper reading of the "economic interest" test as an "invade and dominate" test would exclude many beneficial tie-ins from the per se rule and use instead the rule of reason to explore any anticompetitive effects of the particular tie at issue.

Under both the per se rule and the rule of reason, a plaintiff must establish a substantial danger that the seller will use the tie-in to acquire market power in the tied product market. ${ }^{166}$ The Moore "indirect economic interest" test might be said to be coming at the problem from the wrong direction. The court in Miller Motors recognized that Ford's tie-in was not just harmless, but beneficial, and devised the economic interest test to keep the tiein from being declared illegal. Other courts have noted that there is no economic difference between direct and indirect economic interest. Nevertheless, as in Moore, instead of excluding direct economic interests from per se illegality, they have included indirect economic interests. The economic interest test from Miller Motors was misnamed, then misread, misapplied, and misused.

Fortunately, Jefferson Parish is open-ended enough to allow lower courts a great deal of discretion to use a more economically sensible standard. Courts should return to the Miller Motors "invade and dominate" economic interest standard. Under this standard, tie-ins for which no Jefferson Parish non-leverage harm

${ }^{166}$ Jefferson Parish, 466 US at 31; Carl Sandburg Village Condominium Association No. 1 v First Condominium Development Co., 758 F2d 203, 207, 210 (7th Cir 1985). 
is alleged should be ruled per se legal. Relying on an "indirect economic interest" test stands the reasoning behind the economic interest test on its head, and is an inappropriate judicial standard inconsistent with prior appeals court decisions and with Jefferson Parish. On the contrary, the invade-and-dominate test should be expanded to reach cases where there is a traditional direct economic interest. Courts could judge such defendants by the rule of reason test, examining actual effects on the tied product market instead of declaring potentially benign practices per se illegal. 
